Itinerario, Vol. 44, No. 2, 446-470. (C) The Author(s), 2020. Published by Cambridge University Press on behalf of Research Institute for History, Leiden University. This is an Open Access article, distributed under the terms of the Creative Commons Attribution-NonCommercial-NoDerivatives licence (http://creativecommons.org/licenses/ by-nc-nd/4.0/), which permits non-commercial re-use, distribution, and reproduction in any medium, provided the original work is unaltered and is properly cited. The written permission of Cambridge University Press must be obtained for commercial re-use or in order to create a derivative work.

\title{
Cosmotopia Delineated: Rammohun Roy, William Adam, and the Calcutta Unitarian Committee
}

\author{
CLARE MIDGLEY* \\ Email: C.C.Midgley@shu.ac.uk
}

This article seeks to establish the value of the concept of cosmotopia to historians of intercultural connections through presenting a case study of the Calcutta Unitarian Committee, which was active between 1821 and 1828. In tandem, it aims to enhance understanding of the origins of one particularly sustained set of intercultural connections: the interfaith network which developed between an influential group of Hindu religious and social reformers, the Brahmo Samaj, and western Unitarian Christians. The article focusses on the collaboration between the two leading figures on the Committee: Rammohun Roy, the renowned founder of the Brahmo Samaj, who is often described as the Father of Modern India; and William Adam, a Scottish Baptist missionary who was condemned as the "second fallen Adam" after his "conversion" to Unitarianism by Rammohun Roy, and who went on to cofound a utopian community in the United States. It explores the Calcutta Unitarian Committee's activities within the cosmopolitan milieu of early colonial Calcutta, and clarifies its role in the emergence of the Brahmo Samaj, in the development of a unique approach to Christian mission among Unitarians, and in laying the foundations of a transnational network whose members were in the vanguard of religious innovation, radical social reform, and debates on the "woman question" in nineteenth-century India, Britain, and the United States. In conclusion, the article draws on the case study to offer some broader reflections on the relationship between utopianism, cosmopolitanism, and colonialism.

Keywords: Cosmotopia, Rammohun Roy, William Adam, Calcutta Unitarian Committee, Brahmo Samaj

This article seeks to establish the value of the concept of cosmotopia for historians of intercultural connections through presenting a case study of the Calcutta Unitarian 
Committee, which was active between 1821 and 1828. In tandem, it aims to enhance our understanding of the origins of one particularly sustained set of connections: the interfaith collaboration, over the course of the nineteenth century, between an influential group of Hindu religious and social reformers, the Brahmo Samaj, or Society of Worshippers of the One Supreme Being, and western Unitarian Christians, heterodox Protestants who rejected the doctrine of the Holy Trinity and believed in the unity of God, and who were prominent in social reform movements in both Britain and America.

In identifying the Calcutta Unitarian Committee as a cosmotopia within a colonial context, this article highlights its character as a transnational and transcultural utopian space of interaction. Anja Müller and Clare Wallace pioneered the use of the concept of cosmotopia in their 2011 study of contemporary Scottish playwright David Greig, but it has not previously been taken up by historians. They coined the term to encapsulate Greig's attempt to create a utopian transnational space where people with different national, ethnic, class, or religious backgrounds could transcend restrictive national identities and negotiate their positions, perspectives, and identities within a search for a common humanity. Grieg's theatrical events, they argue, act as spaces where people come together to create a sense of community through finding common ground across entrenched social and cultural boundaries, which they can then seek to extend outwards into the world beyond that space. ${ }^{1}$ This article seeks to demonstrate that the concept of cosmotopia can be of value to the study of the colonial past as well as the neocolonial present, and be applied to diverse social and cultural spaces beyond those of the Western theatrical performance. The concept, it suggests, can encourage historians to make productive connections between hitherto largely disconnected bodies of scholarship on cosmopolitanism and utopianism.

Substantial, but largely distinct, bodies of scholarship on cosmopolitanism and utopianism root both in Western intellectual traditions dating back to classical antiquity. The term cosmopolitan, derived from the Greek words for "world" (cosmos) and "city" (polis) is associated with Enlightenment philosopher Immanuel Kant's ideal of the "citizen of the world," while the vision of "utopia," with its double meaning (again in the Greek) of both "good place" and "no place," is traced to Sir Thomas More's imagining of an ideal society set on an Atlantic island in his 1516 book Utopia. $^{2}$ More recent scholarship, however, has broadened understandings of both cosmopolitanism and utopianism, past and present, identifying rooted, vernacular, and subaltern as well as elite forms of cosmopolitanism, and utopian traditions developed outside the West. $^{3}$

In its delineation of the cosmotopian nature of the Calcutta Unitarian Committee, this article develops on this global turn in scholarship on cosmopolitanism and utopianism, particularly as it focusses on South Asia. It draws inspiration from Sugata Bose and Kris Manjapra's concept of "cosmopolitan thought zones" and their identification of "aspirational cosmopolitanism" as the "pursuit of conversations across lines of difference, between disparate socio-cultural, political and linguistic groups, that provisionally created shared public worlds." Their formulation of cosmopolitanism as developed in dialogue rather than as an individual state of mind suggests the importance of examining 
organisations which fostered such dialogue, including the Calcutta Unitarian Committee. Interpretation of this Committee also needs to be informed by an understanding of the colonial context within which it operated: as Bose and Manjapra note, aspirational cosmopolitanism was marked by "irreducible incongruities of power," and Peter Van der Veer distinguishes between "colonial" and "anti-colonial" cosmopolitanisms in colonial India. ${ }^{5}$ Barnita Bagchi, in contrast, avoids such a binary model in her analysis of the distinctive trajectories of South Asian utopianisms, emphasising how these developed "in the especially hybridized world set in place after the onset of British colonialism." 6

Bagchi's work has a particular connection to the empirical focus of this article: most of the utopian women and men she discusses were Bengalis who belonged to, or had close links with, the Brahmo Samaj, the influential organisation for religious and social reform among Hindus which was founded by Rammohun Roy following his involvement in the Calcutta Unitarian Committee. ${ }^{7}$ This raises the question of whether elements of the utopianism Bagchi identifies in the late nineteenth and early twentieth centuries might be traceable back to this Committee. The potential for exploring both utopianism and cosmopolitanism in early colonial India through the lens of the Committee is further suggested by existing scholarship on its cofounders: Rammohun Roy, revered by many as the founding father of modern India, and William Adam, a far more obscure historical figure. In his recent critical biography of Rammohun Roy, for example, Adiya Sen concludes that Roy was a rooted cosmopolitan, who "anticipated the cosmopolitanism of Gandhi which allowed for people to be firmly rooted in their own cultures while also leaving their doors wide open for the richness of human experiences." offers complementary insights, emphasising Roy's pivotal role in creating "a cosmopolitan world" connecting Britain and India and his role in expanding the cosmopolitan outlook of British Unitarians. ${ }^{9}$ Turning to William Adam, after leaving Bengal he cofounded a radical abolitionist utopian community in the United States, and Christopher Clarke suggests several ways in which Adam's earlier years in India and collaboration with Roy "gave him connections and ideas which would indirectly pave the way to involvement" in this utopian experiment. ${ }^{10}$

The Calcutta Unitarian Committee has not itself been the focus of detailed study. It barely features in the history of Unitarianism, and scholars have instead focussed on the role of Rammohun Roy as an individual in forging links with western Unitarians. ${ }^{11}$ In addition, the Committee's relationship to the foundation of the Brahmo Samaj is contested: David Kopf asserts its foundational importance, ${ }^{12}$ whereas Bruce Carlisle Robertson claims that founding the Brahmo Samaj in 1828 "signalled Rammohun's final split with Unitarians in Bengal," 13 a conclusion which has in turn been challenged by Lynn Zastoupil, who discusses Roy's close collaboration with Unitarians in Britain in the 1830 s. $^{14}$

This article seeks to present a fuller picture of the Calcutta Unitarian Committee and to re-evaluate its significance. It draws on a range of primary sources, including the publications of the Committee, the correspondence of Rammohun Roy, and the Committee's manuscript memoranda book, which has not previously been consulted by scholars. This material is all in English, which by the 1820s had become the language of dialogue 
between educated Bengalis and Westerners in colonial Calcutta. It is important to note, however, that Roy was simultaneously engaged in publishing in Bengali and editing Bengali-language periodicals. ${ }^{15}$ Study of these, and of a wider range of Bengali-language material — a task beyond the linguistic competence of the author of this article-would doubtless throw additional light on the Committee, and on Bengalis' attitudes towards it.

The article begins by sketching out the context of colonialism, cosmopolitanism, and religious controversy within which the Committee cofounders, Rammohun Roy and William Adam, first encountered each other in Calcutta. It moves on to explore the composition, objectives, and activities of the Committee, and it then examines the significance of its transformation in 1828 into the British Indian Unitarian Association, and Roy's decision to then found his own new organisation, the Brahmo Samaj. Finally, it discusses the role of the Committee's work in the foundation of a long-lasting transnational interfaith network. In the process, it delineates the nature of the Committee as a cosmotopian space. The conclusion draws out the historical significance of the Committee, and it discusses how this case study points to ways in which the concept of cosmotopia might fruitfully be mobilised more widely by historians.

\section{Rammohun Roy and William Adam in Early Colonial Calcutta: Colonialism, Cosmopolitanism, and Religious Controversy}

The Calcutta Unitarian Committee was founded in 1821 following meetings in Calcutta between two men from very different backgrounds: the Bengali intellectual and reformer Rammohun Roy and the Scottish Baptist missionary William Adam. Calcutta in the early nineteenth century was fast becoming the "second city of empire," transforming from a key trading hub of the East India Company into the governmental base of the "Company Raj." Rammohun Roy was born in Bengal in 1772 or 1774, just after the East India Company had seized control over the region and been granted revenue-collecting rights by the Mughal emperor. He was born into a Brahmin (high priestly caste) family with a history of service to the Mughals and was himself employed for a time by the East India Company, though he gained most of his income from his rural estates. In 1815 Roy settled in Calcutta, where he gained fluency in English and became prominent in Bengali intellectual circles. ${ }^{16}$

Calcutta at this time was not only a hub of British imperial power but also a cosmopolitan port city with a growing population of diverse ethnic, linguistic, and religious backgrounds. ${ }^{17}$ Circuits of trade also enabled the transoceanic circulation of knowledge, and Roy and his friends were keen to learn about Western scientific developments, intellectual traditions, and political movements. At the same time, some European intellectuals developed a deep interest in ancient Hindu civilisation, language, and religion. Interchange of knowledge cultivated cosmopolitan outlooks, but it was also entangled in the agenda of colonial governance. The East India Company sought to understand Indian religions, cultures, and languages as a tool for ruling over the colonised "other"; from the mid-1820s it also sought to create an Anglicised Bengali middle 
class - the bhadrolok - who would form an army of clerks servicing its administration and also act as intermediaries between the white British ruling elite and the colonised Indian masses. ${ }^{18}$ This group were more than colonial collaborators, however: they developed a new civic culture, forming institutions and associations and founding newspapers and periodicals, initiatives in which Roy played a leading role and which led him into campaigning for press freedom alongside the radical British journalist James Silk Buckingham, an outspoken critic of East India Company governance. ${ }^{19}$ This was also a time when, as Brian Pennington points out, Hindus such as Roy "entered into a dialectic space in which they endorsed and promoted the British publication of ancient texts and translations, resisted missionary polemic, and experimented with modifications, alternations and innovations in Hindu religious forms." 20

William Adam's path crossed with Roy's soon after Adam arrived in India as a Baptist missionary in 1818 . This was because Roy was at this time engaged in detailed discussions about religion with Baptist missionaries, from whom he was keen to find out more about Christianity. ${ }^{21}$ To the anger of orthodox Brahmins, Roy was seeking to promote a monotheistic interpretation of Hindu sacred texts, arguing that their essential message, as articulated in the Vedas, was that of the unity of the supreme being, and condemning the practice of worshipping a multiplicity of manifestations and images of this supreme being. In 1815 he had gathered together a group of Bengali intellectuals in an association called the Atmiya Sabha to challenge the religious establishment. ${ }^{22}$ There is evidence that by this date he had already become aware of, and sympathetic to, the heterodox Unitarian strand within Protestant Christianity, which rejected the doctrine of the Holy Trinity. The first Anglican bishop of Calcutta, T. F. Middleton, noted that Roy had told him he planned "to form a 'Unitarian Society' in Calcutta" but that the bishop had dissuaded him, and Roy had instead called it "the Friendly Society," his English translation of Atmiya Sabha. ${ }^{23}$ In an English-language letter published in 1819 Roy refers to this Friendly Society as "the Brahmyu or Unitarian Hindoo community," suggesting the way in which he had already begun to identity his religious group as Brahmos and to translate this into English as Unitarian Hindus. ${ }^{24}$ He published a series of works in Bengali promoting his religious ideas, some of which he translated into English. The titles, A Defence of Hindoo Theism (1820) and A Second Defence of the Monotheistical System of the Veds (1820) indicated that "Hindoo theist" and "monotheist" were further alternative translations of his religious positioning for the benefit of an English-language readership. ${ }^{25}$

Baptist missionaries were hopeful that Roy's advocacy of Hindu monotheism marked a staging post in his conversion to Christianity, and Roy's exchanges with Baptist missionaries started on a positive note. Roy was deeply impressed by the ethical teachings of Christ, ${ }^{26}$ while the Baptist missionaries applauded his public opposition to widowburning, publishing one of his anti-sati tracts and drawing on his interpretations of the Hindu scriptures in reworking their own arguments against the practice. ${ }^{27}$ Baptists' high hopes that Roy would become a prestigious convert to Christianity were, however, misplaced, and Roy's publication in 1820 of his tract The Precepts of Jesus marked a breaking point in their cooperation with Roy. ${ }^{28}$ The Rev. Joshua Marshman publicly denounced the book as the work of a "heathen" who had perverted the gospel by omitting 
key theological passages and miracle stories. ${ }^{29}$ A war of words broke out, with Roy defending his work vigorously in his Appeal to the Christian Public, in which he argued that the passages from the Bible he had quoted laid out a complete path to salvation through service and concluding with a universalist religious plea: "May God render religion destructive of differences and dislike between man and man, and conducive to the peace and Union of mankind. Amen."30

In the months leading up to his publication of The Precepts of Jesus, Roy had started to meet regularly in Calcutta with William Adam and his fellow Baptist missionary William Yates. William Adam was a much younger man than Roy, born in Scotland in 1796. He had arrived in India from Britain in March 1818 after training as a Baptist missionary and initially joined the Baptist Missionary Society's main mission in Serampore to the north of Calcutta before moving with two colleagues to Calcutta, where they set up a chapel and a mission base just outside the city. ${ }^{31}$ Roy worked in Calcutta with Adam and Yates on new translations into Bengali of the four Gospels, seeking to correct what he identified as inaccuracies in the existing Serampore missionary translation. Yates, however, rapidly broke with Roy because he regarded Roy's proposed retranslations as undermining the Trinitarian doctrine that Christ was coeternal and consubstantial with the Father. Adam, in contrast, started to question his religious beliefs under Roy's influence. He took the dramatic step of publicly rejecting the doctrine of the Holy Trinity and avowing himself a Unitarian, a move which resulted in his excommunication from Circular Road Baptist Chapel in Calcutta in September 1821, and his dismissal from employment by the Baptist Missionary Society in Britain. Adam was derided as "the second fallen Adam," and there was particular anger and concern at Roy's role in turning the world of missionary conversion upside down. As the Rev. William Ward of Serampore wrote in November 1821: "The heathen Ram Mohunroy converting a Missionary! How we are fallen!" 32 Such were the dramatic circumstances in which the Calcutta Unitarian Committee was born.

\section{Cosmotopia Created: The Calcutta Unitarian Committee}

The Calcutta Unitarian Committee, jointly founded by William Adam and Rammohun Roy in September 1821, sought to bring together prominent Brahmins who were friends of Roy's and supporters of his agenda for the promotion of religious monotheism and social reform among Hindus with British and European residents of Calcutta who were Unitarian Christians. For Roy, the Committee acted as a new associational focus following the demise of the Atmiya Sabha in 1819. ${ }^{33}$ For Adam, now unemployed and ostracised by his former Baptist missionary brothers, collaboration with Roy opened up the prospect of funding, employment contacts, and entry into elite cross-cultural networks in the city. For both men, it formalised their earlier collaboration in promoting a Unitarian interpretation of the Bible, while also providing a space to foster broader collaboration between Unitarian Christians and Hindu monotheists.

Constructing an accurate picture of the shifting membership of the Committee is a complex task, but surviving records suggest that William Adam and Rammohun Roy 
were joined on the founding committee by George James Gordon, a merchant of the firm of Mackintosh \& Co., who acted as treasurer, William Tate, an attorney, and Dwarkanath Tagore, a wealthy and prominent businessman. These three British and two Bengali men formed the stable core of the Committee. Roy's friend Sandford Arnot was also a member before his deportation to Britain at the end of 1823 for journalism critical of the colonial establishment. In November 1825 the Committee was expanded to include Theodore Dickens, a barrister in the supreme court, B. W. McLeod, a surgeon in the East India Company's service, William Bruce, and Prusunnu Coomar Tagore, a lawyer and campaigner against suttee. Three other British men, Norman Kerr, C. G. Strettell, and Samuel Smith, also served on the Committee in $1827 .{ }^{34}$

In bringing into voluntary collaboration on the basis of equality Europeans and Indians, Hindus and Christians, the Committee created a cosmotopian space within a colonial environment marked by racialised hierarchies of power and by hostility between orthodox Hindu religious leaders and Christian missionaries. Of course, it was also a highly imperfect cosmotopia. It was exclusively male-Bengali women did not begin to enter into public associations until the mid-1860s and $1870 \mathrm{~s}$, while the lack of British and American Unitarian women on the Committee accorded with women's exclusion from positions of ministry and authority within the Unitarian movement at this period. ${ }^{35}$ The Committee was also socially exclusive in both class and caste terms, involving educated professionals and merchants on the European side, and wealthy Western-educated Brahmins on the Bengali side. ${ }^{36}$

The Committee also included no Muslim members. This is not surprising, given that, despite the absence of the word "Christian" from its title, the Committee's primary object was "to promote the knowledge, belief, and practice of the principles of Unitarian Christianity throughout British India." ${ }^{37}$ Why then did Roy decide to join with Adam in creating a Committee which combined an interfaith membership with a restricted single-faith objective? To understand this it is necessary to explore the differing religious perspectives and motivations of Adam and Roy, and to unpick the differing but complementary agendas that they were able to pursue under the umbrella of the Committee.

Adam, in becoming a Unitarian, had aligned himself with a strand of Protestantism which had no history of foreign missionary work. He was no longer concerned, in contrast to his former Baptist missionary colleagues, with saving heathen souls from eternal damnation through conversion, as Unitarians did not believe in the Calvinist doctrine of original $\sin ^{38}$ However, he continued to believe in the superiority of Christianity over other religions. He wanted to promote Unitarian Christianity in India, first by getting support from among its European Christian population, then by focussing on "the influential classes of the Native community." 39 He hoped that Roy's Hindu monotheism and reverence for Jesus's teachings would, in the long term, become a bridgehead to the spread of Unitarian Christianity through India. Roy was also his friend, and the person who had "converted" him from Trinitarianism to Unitarianism.

Roy shared with Adam a rationalist approach to religion. However, unlike Adam, he was a universalist in the sense that he identified common ground between different religious traditions in an underlying fundamental belief in one supreme being. His approach was 
also eclectic: he wanted to draw on what he identified as the positive aspects of Christianity, and in this spirit, he was happy to join with Adam in promoting knowledge of the Unitarian form of Christianity in India and in presenting Jesus to Indians as the most inspirational moral and ethical teacher the world had yet seen. However, Roy remained a Hindu and drew on Hindu sacred texts as the source of religious authority for his monotheism. His key objective was to reform Hindu religion and culture from within. ${ }^{40}$

The Committee was able to square its interfaith membership with its aim of promoting Unitarian Christianity through careful wording of this aim and through articulating a wide range of means to achieve it. It avoided the standard Christian missionary language of the conversion of the heathen and placed an emphasis on the diffusion of religious principles rather than doctrine. In this way it opened up a cosmotopian space for active contributions by Hindu monotheists as well as Unitarian Christians. Positioning itself as an endeavour to open up Indian hearts and minds to "rational" and "true' religion," 41 it left the definitions of these terms open to both Christian- and Hindu-inflected interpretations. It also laid out an ambitious pathway for achieving this to which Christian Unitarian and Hindu monotheist could equally contribute, starting with philanthropic work to improve everyday lives, and proceeding thorough educational initiatives to "destroy ignorance and superstition, bigotry and fanaticism, to raise the standard of intellect, to purify the theories of morals, and to promote universal charity and practical benevolence, although not in immediate connexion with Christianity." ${ }^{, 2}$ This approach was in tune with Roy's belief in the interconnection between religious and social reform.

Adam and Roy pursued this agenda in distinctive but complementary ways. Adam's first step was an attempt to establish a Unitarian ministry in Calcutta with the intention of creating a solid public Unitarian presence in the city, diffusing accurate information about Unitarianism among educated Christians, Hindus, and Muslims, and establishing a congregation which could be "a focus from which the light of pure religion would emanate in many different directions." Committee's rented meeting room. These were attended by the small group of western Unitarian Christians resident in Calcutta and by some of Roy's group of Hindu monotheists. However, despite financial support from Roy, Adam had to abandon this work after about a year as his lack of a regular ministerial income meant he needed to take secular employment as a journalist to support his family. ${ }^{44}$ In addition, appeals for support to enable the building of a Unitarian chapel in Calcutta, despite attracting subscriptions from twenty-seven individuals including Roy and eight of his Bengali associates, failed to raise sufficient funds. ${ }^{45}$ With Adam's ministerial work on hold, the Committee sought an alternative way of diffusing Unitarian Christianity in India through launching The Unitarian Repository and Christian Miscellany in September 1823. However, this ran for only a year, struggling to gain sufficient subscribers. ${ }^{46}$

Rammohun Roy meantime focussed his efforts on the educational objectives of the Committee. In 1822 he established the Anglo-Hindoo School in Calcutta, which offered free instruction to sixty to eighty Bengali Hindu boys in English language and general knowledge. While this operated independently of the Calcutta Unitarian Committee, it was publicly acknowledged in reports of the Committee as forwarding its objectives 
of using education "for the renovation and improvement of the Hindoo character." ${ }^{, 47}$ Roy also founded and funded the Unitarian Press in 1821, which published tracts promoting both Unitarian Christianity and Hindu monotheism and social reform. One of its first publications was a sermon on Unitarianism preached by its leading American proponent, William Ellery Channing. ${ }^{48}$ The press also published the reports of the Calcutta Unitarian Committee, Roy's final tract in defence of his Unitarian interpretation of the Bible ${ }^{49}$ the Brahmunical Magazine, a witty repost to attacks on Roy's religious position from both orthodox Hindus and orthodox Christians, and tracts by Roy promoting Hindu religious reform and arguing for the restoration of Hindu women's ancient legal rights. ${ }^{50}$ The cultivation of a free "spirit of enquiry" into religion was also advanced by the Committee setting up the Calcutta Theological Library, which offered free access for all. Shaped by Roy's deep interest in the comparative study of religion, it was founded "with a view to facilitate the most extended comparisons and references, to include the standard Theological works of the religions and sects of all nations and ages." ${ }^{.51}$

Adam was keen not to confine his activities to a ministerial role: he had ambitions also to launch a Unitarian Christian mission to Indians. To achieve this, he realised that he would need overseas aid, and, in his capacity as secretary of the Calcutta Unitarian Committee, he wrote in 1822 to the Unitarian Fund in London not only seeking funding for the erection of a Unitarian chapel in Calcutta and the provision of printing materials for the Unitarian Press, but also seeking backing for his ambitious plan for a total of sixteen Unitarian missionaries to be based in the Presidency capitals of Calcutta, Bombay, and Madras, and in Colombo, Ceylon, with four printers to support their work. ${ }^{52}$ Simultaneously, he contacted the leading promoter of American Unitarianism, William Ellery Channing, seeking American support for these plans. His requests met with a cautious response, with British Unitarians indicating they might be able to raise up to $£ 500$ towards the building of a chapel, ${ }^{53}$ while Henry S. Ware, Professor of Divinity at Harvard College in Cambridge, Massachusetts, independently sent both Adam and Roy a list of twenty searching questions concerning the "prospects of Christianity and the means of promoting its reception in India" in order to determine whether a Unitarian mission in India had any prospect of success. ${ }^{54}$

Adam's long and detailed response to Ware articulated the specific Unitarian approach to foreign mission that he had developed through dialogue with Roy and members of the Calcutta Unitarian Committee. This presented it as a long-term project which needed to begin not by attempting dramatic conversions of the "heathen" but by founding missionary schools which spread "the universally-acknowledged, the simple, and rational truths of religion" rather than Christian dogma, and by working to "awaken the dormant reason and conscience of intelligent natives" who "must ultimately be the chief instruments" of the propagation of Christianity. ${ }^{55}$ Roy's response, sought because of his acknowledged expertise in the comparative study of Hinduism and Christianity, was subtly different. He was asked by Ware whether he "think it desirable, that the inhabitants of India should be converted to Christianity; in what degree desirable, and for what reasons?" ${ }^{56}$ In response Roy articulated his universalist belief that fundamental religious truths transcended specific religious traditions. In his words: "I pause to answer, as I am led to 
believe, from reason, what is set forth in the scripture, that 'in every nation he that feareth God and worketh righteousness is accepted with him,' in whatever form of worship he may have been taught to glorify God." He made it clear that it was Jesus as moral example, not Christianity as a set of religious doctrines, that he valued. ${ }^{57}$ "True religion" could triumph if American Unitarians sent out not missionaries but "teachers of European learning and science and Christian morality, unmingled with religious doctrines.. ${ }^{58}$ Adam was clearly still the Christian missionary at heart, struggling to find the best way to eventually achieve conversions, while Roy did not see the necessity for conversion at all.

As the result of the publicity surrounding these exchanges, modest amounts of funding began to flow into Committee coffers from overseas. ${ }^{59}$ The Committee also sought to drum up support from Unitarian Christian residents of Calcutta through publication in 1825 of their Brief Memoir Respecting the Objects and Means of Establishing a Unitarian Mission in Bengal, which reiterated the importance of adopting a rational and educational approach to promoting Christianity in India. ${ }^{60}$ Membership in the Committee expanded, and it began to hold regular monthly meetings. ${ }^{61}$ In February 1826, seizing the opportunity afforded by the foundation in 1825 of national Unitarian organisations in both Britain and the United States, Adam made a renewed request for funds to support his own work as minister and missionary. He addressed both W. J. Fox, the foreign secretary of the British and Foreign Unitarian Association (BFUA), the new British national Unitarian body which included support for foreign missions in its founding resolutions, and Joseph Tuckerman, the secretary of the Society for the Promotion of Christianity in India, also known as the Boston India Association. This organisation had been set up in February 1825 in parallel to the American Unitarian Association to focus on developing Unitarian missions overseas, with Reverend Henry Ware as its president. ${ }^{62}$

In response, Tuckerman published a letter laying out Unitarian missionary principles and advocating support for the Calcutta Unitarian Association, while the BFUA embarked on discussions and an exchange with Adam on the merits of supporting a mission in India. ${ }^{63}$ This eventually led to both the Boston India Association and the BFUA guaranteeing annual contributions to Adam's salary which, when combined with a matching amount from the Calcutta Unitarian Committee's own missionary fund, gave him a total salary of 350 rupees a month. On the basis of this guaranteed funding, on 1 May 1827 Adam was formally engaged by the Committee as Unitarian minister and missionary, though on a part-time basis as the salary alone was inadequate to support his family. ${ }^{64}$ Despite subscriptions raised in Calcutta, Britain, and the United States, there were still insufficient funds to build a chapel, a move the Committee considered essential to the creation of a permanent Unitarian congregation and solid religious presence in the city. ${ }^{65}$ Nevertheless Adam recommenced public Unitarian Christian services for worship using rented rooms, and, according to the published report at least, attendance grew rapidly to fifty to eighty individuals. He also delivered a series of evening lectures on religion attended by both Hindus and Europeans interested in "the Doctrine of the Unity of God considered in its various relations both to Trinitarianism and to 
Polytheism and Idolatry." 66 In addition he launched a weekly "Native Service" in English intended to "form a point of union between Christian and Hindoo Unitarians against polytheism and idolatry" through focussing on the "inculcation of moral and religious obligations on rational principles." $" 67$ The Committee also decided to publish its principles, objects, and rules to try to drum up further local support. ${ }^{68}$ In addition, Adam discussed with Committee members the possibility of a visit to Madras, having been put in touch by British Unitarians with William Roberts, a Christian convert who had independently formed an indigenous Indian Unitarian congregation in Madras several years before the formation of the Calcutta Unitarian Committee. ${ }^{69}$

\section{Cosmotopia Dissolved or Reshaped? The British Indian Unitarian Association and the Brahmo Samaj}

Despite positive public reports of its activities, however, problems soon emerged. The unpublished memoranda of the Committee indicate that there was a rapid fall-off in attendance at Adam's services and lectures, perhaps as their novelty wore off. ${ }^{70}$ In September 1827 Adam suggested that, to encourage further financial support, the Committee transform itself into a "regularly organised Society" and, after discussions with Roy and other Committee members, a general meeting was convened on 30 December. ${ }^{71}$ The published report of this meeting indicates that its Hindu supporters sought to ensure the reconstituted group would continue as an interfaith organisation: Dwarkanath Tagore, formally proposing the name change to the British Indian Unitarian Association (BIUA), specified that the new organisation should have "the same objects and principles as the Calcutta Unitarian Committee," while Tarachand Chakravarti, a friend of Roy's who was not himself a Committee member, proposed that the current members of the Committee be requested to act as the Committee for the new association for its first year. Nevertheless, the differing priorities of Adam and Roy regarding the reorganised group are suggested by the content of the resolutions they each put forward: William Adam, clearly pinning his hopes on collaboration with western Unitarians, proposed that the meeting "views with deep interest the combined exertions of English and American Unitarians to establish a Mission in this country" and "pledges itself to zealous and persevering co-operation with them." In contrast, Rammohun Roy focussed on expansion beyond Calcutta as a collaborative effort between Christian Unitarians and Hindu monotheists, proposing "That this Meeting invites all Unitarians, whether Christian or Hindoo, to form themselves into Associations auxiliary to the British Indian Unitarian Association."72

The attempt to reinvigorate Unitarianism in Calcutta and spread it more widely through India was not a success. Within a few months, Adam was expressing despondency at his lack of progress as missionary and minister. Roy generously offered to underwrite the cost of building the long-planned Unitarian chapel in Calcutta, but the Committee decided not to take up his offer because of the absence of a solid congregation. ${ }^{73}$ Adam, struggling to support his family and forced to focus more of his time 
working as a journalist, decided in June 1828 that he could no longer justify claiming his salary as missionary and minister, and a letter was dispatched to Unitarian supporters in Britain and America informing them of the state of affairs. ${ }^{74}$

Only eight days later Adam circulated to Committee members a circular letter from the "Hindoo Unitarian Association," which he described as "an institution just formed in the city with a view to extend the knowledge and worship of one God amongst the Hindoos in opposition to the prevalent idolatry." He acknowledged that "in the great work of the moral and religious regeneration of India, the Hindoos themselves, if not the first, must be the principal agents employed" and proposed to the Committee "that a 'grant' of $500 \mathrm{R}$ [upees] be made in aid of the objects of the Hindoo Association from the friends of the British Indian Association as a proof of the interest we take in their proceedings and in order to strengthen that friendly feeling which already so happily exists between Christian and Hindoo Unitarians." He noted that most Committee members had already subscribed individually but argued that "a donation from the friends of the Committee would carry great weight with it as representing the sentiments of the body of Calcutta Unitarians." He accompanied his proposal with a copy of the address published by the new group in English and Bengali, together with a list of "subscriptions both European and Native." The Committee members signing off in support of the proposal included Rammohun Roy, the founder of the new organisation. ${ }^{75}$

The new evidence provided by the Calcutta Unitarian Committee's memoranda book enables an important clarification of the relationship between the Calcutta Unitarian Committee/BIUA and the new Hindu group founded by Roy. Rather than the breakdown of collaboration between Roy and Adam suggested by some previous scholars, the records show that, at Adam's instigation, the BIUA publicly lent its support to Roy's new group. In addition, both Roy and Dwarkanath Tagore continued to be members of the BIUA's committee until it was formally wound up, at Adam's instigation, at the end of $1829 .^{76}$

Adam had been encouraging the formation of a Hindu Unitarian auxiliary to the BIUA in Calcutta, harbouring the hope that it would be only nominally Hindu, and would lay the ground for Unitarian Christianity. ${ }^{77}$ Roy, who had himself formally proposed the formation of auxiliary associations to the BIUA, may have considered positioning his new organisation as such an auxiliary. However, in the event he decided to found an independent organisation. This was probably partly because the BIUA was already clearly failing, partly because he wanted to make the new group attractive to a wider range of Hindus who supported religious and social reform but did not want to be associated with the explicitly Christian agenda of the BIUA. ${ }^{78}$ Adam was disappointed when he realised that the religious identity of the new group was to be explicitly based on the Hindu Vedas, with no reference to the Christian scriptures. Writing to his American Unitarian backer Joseph Tuckerman at the beginning of 1829, he explained: "There has . . . been formed a Hindu Unitarian Association, the object of which is, however, strictly Hindu and not Christian.. . This is a basis of which I have distinctly informed Rammohun and my other native friends that I cannot approve."79 
By 1830, when the new group established its own place of worship, Roy had ceased to refer to the group as the Hindoo Unitarian Association; it had become the Brahmo Samaj, or Society of Worshippers of the One Supreme Being. William Adam had already made the decision to wind down the BIUA, writing to Committee members in November 1829 to gain their agreement to return funds subscribed by donors and close its accounts at the end of the year. ${ }^{80}$ Rammohun Roy and Dwarkanath Tagore, key financial supporters of the old Committee, were now free to focus their funds on creating a permanent place of worship for the new group. There Roy developed new forms of divine worship which eschewed idolatry and animal sacrifice and promoted a social reform agenda focussed on outspoken opposition to suttee, the practice of burning widows on the funeral pyres of their husbands.

Roy, however, retained his desire to reach out beyond the Hindu community. The Trust Deed for the group's new place of worship stated that the Brahmo Samaj would welcome "people without distinction" for the worship of the "Author and Preserver of the Universe" and for "the promotion of charity morality piety benevolence virtue and the strengthening the bonds of union Between men of all religious persuasions and creeds [sic]." ${ }^{81}$ The cosmotopianism of the Calcutta Unitarian Committee thus did not vanish with the demise of the BIUA; rather, it manifested in a new form, with a central focus on reforming Hinduism from within under Roy's religious leadership rather than on expanding knowledge of Unitarian Christianity through Adam's ministry and missionary work. This marked the foundation of a long-lived, influential, and outward-looking movement for religious and social reform among Hindus. ${ }^{82}$

\section{Cosmotopia Continued: Transnational Networks of Religion and Reform}

At the heart of the outward-looking perspective of the Brahmo Samaj lay its continuing relationship with western Unitarians, a relationship rooted in the participation by Roy and his fellow Hindu monotheists in the Calcutta Unitarian Committee. From the outset the Calcutta Unitarian Committee had positioned itself as an outward-facing hub of communication: its founding rules stated that "Unitarians in India, England, and America shall be invited to co-operate with this Committee." ${ }^{83}$ This cooperation was fostered by both Adam and Roy, who initiated parallel streams of correspondence with leading British and American Unitarians. This correspondence, as well as bringing in overseas financial support for the Committee's work, had a number of important long-term impacts which persisted well beyond the demise of the Committee itself.

In the first place, it was Adam and Roy's communications with British and American Unitarians about the prospects for missionary work in India which focussed their minds on the possibility of missionary work overseas. It was Adam, in dialogue with Roy within the cosmotopian space of the Calcutta Unitarian Committee, who first articulated a distinctive Unitarian approach to Christian mission, one which focussed not on conversion as the immediate objective but rather on the spread of Christian moral principles and the cultivation of collaboration with influential Hindu intellectuals like Roy. It was this 
approach to foreign mission, initiated not by leading Unitarian ministers in London or Boston but under the influence of a Hindu reformer in Calcutta, that Unitarians adopted. It was Roy's own reservations about the value of such a mission beyond the purely educational, as expressed in his letter to Henry Ware, that probably also influenced their tentative and limited investment in this overseas mission.

Secondly, Rammohun Roy's correspondence with western Unitarians over the period when he was active in the Calcutta Unitarian Committee informed them about his own approach to religious and social reform among Hindus, as well as his Unitarian interpretation of the Bible. Western Unitarians were not simply interested in supporting Adam's Unitarian Christian missionary work in India; they were equally interested in finding out about Rammohun Roy's movement to reform Hinduism from within. Indeed Roy was already becoming well known as an innovative and outspoken religious thinker and social reformer before his collaboration with Adam. A set of his pamphlets advocating Hindu monotheism were published in London between 1816 and $1819,{ }^{84}$ his tracts opposing suttee were publicised by Baptists in Britain, and his subsequent controversy with the Serampore Baptists over his tract The Precepts of Jesus gained him widespread admiration in Unitarian circles. After the foundation of the Calcutta Unitarian Committee Roy opened a direct correspondence with British Unitarians in 1822 and rapidly developed a network of connections with leading ministers. He was sent books on Unitarianism, his work was reviewed in the Unitarian press, ${ }^{85}$ and a compilation of The Precepts of Jesus and his First and Second Appeals to the Christian Public was published with a preface introducing Roy to a wider British readership. ${ }^{86}$

Roy also began a correspondence with American Unitarians. His initial contact was with the Reverend Jared Sparks, a Unitarian minister in Baltimore who edited the monthly Unitarian Miscellany. ${ }^{87}$ Roy's letters to Sparks have a different tone to those to his British contacts, expressing regard for America as a free nation (clearly referencing its achievement of independence from Britain, while ignoring the institution of slavery), and praising American religious freedom. This suggests that he felt America to be a more congenial ground for establishing intercultural connections than imperial Britain, with its Established Church and religiously marginalised Unitarian community. ${ }^{88}$ His personal engagement with American Unitarians expanded to the main hub of Unitarianism in Boston in April 1823 when he was contacted both by David Reed, editor of the Unitarian Christian Register, and Henry S. Ware, both of whom sought his advice on the likely success of a Unitarian Christian mission to India. ${ }^{89}$ Ware's letter to Roy (briefly discussed in the previous section) made it clear the "high value" he placed on Roy's views as a result of his prior familiarity with Roy's writings on religion, stressing "the very high gratification which I have derived from discussions of the most important subjects of Christian Theology, and interpretations of the Jewish and Christian Scriptures, from the pen of a native of India, bearing such marks of clear and enlightened views, and of extensive and accurate learning, as would do honour to the best educated European divine." 90 The Christian Register also spread Roy's writings in Unitarian circles, distributing his Appeal to the Christian Public and republishing his Precepts of Jesus. ${ }^{91}$ 
Roy's correspondence and exchange of tracts with British and American Unitarians opened up a cosmotopian transnational space for interfaith dialogue which did not close down with the dissolution of the Calcutta Unitarian Committee. Roy continued to build on these connections after he formed the Brahmo Samaj. In 1830 he set sail for England, where he lived for three years, dying in Bristol before he had the chance to fulfil his plan of travelling on to the United States. During his time in England Roy sought to rework on British soil the collaboration which he had forged with Adam in Calcutta, learning more about Unitarian Christianity, spreading information about his movement for religious and social reform among Hindus, encouraging men and women belonging to British Unitarian congregations to petition Parliament to maintain the ban on suttee in colonial India, and convincing Unitarians that lasting social reform within India was most likely to be achieved through the efforts of progressive Indians themselves. $^{92}$

Roy's death in Bristol in 1833 might have marked a final severing of the ties which had grown up between western Unitarians and Hindu monotheists. Roy's religious organisation became inactive, and when it was relaunched in the $1840 \mathrm{~s}$ its new leader, Debendranath Tagore, positioned it as a reformist Hindu sect with no connection to Christianity. ${ }^{93}$ However, a collective transnational memory of Roy as religious and social reformer was retained in both Unitarian and Brahmo circles. ${ }^{94}$ This facilitated the reopening of relations between members of the Brahmo Samaj and western Unitarians in the 1850 s and 1860 s, when a charismatic new leader of the movement, Keshub Chunder Sen, emerged. Sen positioned himself as the true inheritor of Roy's religious movement, and once again took Brahmoism in a universalist direction, declaring his admiration for the teachings of Jesus. Sen and his followers reforged strong links with a new generation of British and American Unitarians, collaborating with them in promoting Indian women's education. ${ }^{95}$

William Adam, after spending a period employed by the East India Company to produce a detailed report on the state of education in Bengal, ${ }^{96}$ left for a new life in Boston in 1838. There he pursued an agenda of radical religious and social reform which continued to make bridges between India, Britain, and America. He briefly held the position of Professor of Oriental Literature at Harvard College, worked as a Unitarian minister, and participated in the transatlantic radical abolitionist network in which Unitarians played an important role. ${ }^{97}$ Perhaps influenced by Roy's earlier advocacy of women's rights in 1820s Calcutta, he spoke out in support of the right of women to participate fully as delegates at the World Anti-Slavery Convention in London in $1840 .{ }^{98}$ At the convention he delivered a paper, "Slavery in India," in which he called for its immediate abolition by the British government, and he continued this campaigning agenda by becoming editor of the British Indian Advocate, journal of the newly founded British India Society. ${ }^{99}$ In his 1840 publication indicting slavery in British India he explicitly positioned himself as a cosmopolitan, referring to himself as "a citizen of the world." 100

Returning to the United States, Adam drew on his links with radical abolitionists and Unitarians to become a founding member of a utopian community in Massachusetts, the Northampton Association, in 1842. It was a venture clearly informed by the cosmotopian 
outlook he had developed in Calcutta. It is easy to see parallels between the agenda of the Calcutta Unitarian Committee in relation to India and the association's attempt to promote the spiritual, moral, and social regeneration of America. The association also sought to uphold the principle of "equal rights" regardless of "sex, color or condition, sect or religion," 101 and was unusual among utopian communities in accepting free black men and women as equal members, including the leading African American abolitionists David Ruggles and Sojourner Truth. Adam's experience of working on equal terms with Indian men in colonial Calcutta may have been a factor influencing this racial inclusivity. Certainly, Adam's friendship and collaboration with Roy remained dear to him, and in 1845 he delivered a lecture in Boston in which he offered a fulsome tribute to Roy's life and work. ${ }^{102}$

\section{Conclusion}

The research presented here establishes the Calcutta Unitarian Committee's historical significance in the face of previous scholarly neglect. It was a key space of interfaith collaboration within the cosmopolitan milieu of early colonial Calcutta. It acted as an important steppingstone both to Rammohun Roy's formation of the Brahmo Samaj, a long-lasting and influential movement for religious and social reform among Hindus, and to William Adam's foundation of a radical abolitionist utopian community in the United States. It played a crucial role in shaping western Unitarianism, initiating a unique approach to Christian mission among Unitarians which stood in sharp contrast to evangelical conversionism. It also acted as the foundational hub of an interfaith network whose members were in the vanguard of religious innovation, social reform, and debates on the "woman question" in India, Britain, and the United States throughout much of the nineteenth century.

The approach and activities of the Committee fit well with the definition of cosmotopia coined by Müller and Wallace to encapsulate David Grieg's theatrical work, suggesting the broader applicability of the concept, and its potential value to historians. The Committee did indeed create a utopian cosmopolitan space where people from different national, ethnic, and religious backgrounds - in this case, Bengali and British, Hindu and Christianfound common ground and worked together across the racialised boundaries of the coloniser-colonised divide. As with all utopian experiments, it was also imperfect: it was exclusive along the lines of class, caste, and gender, and did not attract Muslim support; Roy was open to drawing inspiration from Christianity, whereas Adam believed in the superiority of (Unitarian) Christianity over the monotheistic Hinduism promoted by Roy. Perhaps, drawing on Bose and Manjapra's notion of "aspirational cosmopolitanism," the Committee may best be described as an aspirational cosmotopia.

Engaging further with Bose and Manjapra's work, the way in which William Adam's experiences in Calcutta informed the setting up of a utopian community in America suggests that the "cosmopolitan thought zones" they identify could take a utopian form. The aspiration of early nineteenth-century utopians to create a "new moral world"103 needs to be taken more literally in a geographical sense, with Adam's trajectory suggesting that 
the formation of utopian communities in Britain and America was not exclusively based on the trans-European and transatlantic circulation of ideas. Rather, historians need to be alert to the possibility of multidirectional circulations of utopian impulses within and beyond the bounds of European empires and the Anglo-American world. Indeed, rather than place "western" and "non-western" utopias in separate research boxes, we need to be aware of the likelihood of interconnections and cross-fertilisations.

In this context, Rammohun Roy's involvement in the Calcutta Unitarian Committee suggests that colonised people could play a leading role in creating cosmotopian spaces within colonial environments. Founded amidst the violence and racialised power hierarchies of British colonial expansion, ${ }^{104}$ the Committee acted as one of a number of small islands of respectful cross-cultural collaboration within a sea of imperial domination. It might be possible to identify a tapestry of such cosmotopian spaces within both metropoles and colonies, spaces which modelled alternative forms of peaceful and consensual cross-cultural interaction even when they did not directly challenge institutionalised colonial power.

A case study of the Calcutta Unitarian Committee also suggests that the concept of cosmotopia can usefully be extended to apply not only to localised geographical spaces but also to transnational spaces of mobility, circulation, interaction, and interchange. In identifying one such transnational cosmotopia in the interfaith and intercultural network of connections between western Unitarians and members of the Brahmo Samaj, the findings of this article suggest that it might be fruitful for historians of other transnational networks to consider whether these too functioned as cosmotopian-or at least aspirationally cosmotopian-spaces.

\section{Acknowledgements}

This study has benefitted from funding from Australian Research Council Discovery Project Grant DP170104310, which enabled a visit to Dhaka in March 2019 to deliver a lecture on the topic. My warm thanks to Prof. Asha Islam Nayeem of the Bangladesh Historical Association for arranging this visit. For invaluable comments on earlier versions of the paper, thanks to members of my history writing group, and to participants in the Cosmopolitics Past and Present symposium at Sheffield Hallam University in December 2017 (part of the collaborative project led by Dr. Jane Haggis entitled Beyond Empire: Transnational Religious Networks and Liberal Cosmopolitanisms). Dr. David Wykes of Dr. Williams's Library in London kindly arranged for me to visit the library when it was closed for refurbishment. Finally, thanks to the two anonymous readers of the article for their helpful feedback.

\section{Notes}

- Clare Midgley is Research Professor in History at Sheffield Hallam University and former president of the International Federation for Research in Women's
History. She is author of Women Against Slavery (Routledge, 1992) and Feminism and Empire (Routledge, 2007); coauthor (with J. Haggis, 
M. Allen, and F. Paisley) of Cosmopolitan Lives on the Cusp of Empire (Palgrave Macmillan, 2017); editor of Gender and Imperialism (Manchester University Press, 1998); and coeditor (with A. Twells and J. Carlier) of Women in Transnational History (Routledge, 2016).

1 Müller and Wallace, Cosmotopia.

2 Kleingeld, Kant and Cosmopolitanism; Manuel and Manuel, Utopian Thought in the Western World; Pohl, "Utopianism after More."

3 See, for example, Robbins and Horta, Cosmopolitanisms; Slate, Colored Cosmopolitanism; Alavi, Muslim Cosmopolitanism; Dutton, "Non-Western Utopian Traditions"; Mohan, Utopia and the Village; Bagchi, "Many Modernities and Utopia."

4 Bose and Manjapra, Cosmopolitan Thought Zones, 1.

5 Van der Veer, "Colonial Cosmopolitanism," 175.

6 Bagchi, "Many Modernities and Utopia," p. 218

7 Bagchi, "Towards Ladyland"; Bagchi, Sultana's Dream and Padmarog, introduction.

8 Sen, Rammohun Roy: A Critical Biography, 175. Sen provides an excellent introduction to Roy's life and work, based on a critical evaluation of the rich body of existing scholarship in both British and Bengali/Bangla. Key scholarship in English includes: Collet, The Life and Letters; Joshi, Rammohun Roy and the Process of Modernization; Killingley, Rammohun Roy in Hindu and Christian Tradition; Robertson, Raja Rammohan Ray. Roy's name has variant transliterations into English; I adopt the most commonly used spelling in this article, and have decided to refer to Roy by this, his family name, although in Bengali/Bangla publications it is conventional to use his first name, Rammohun.

9 White, From Little London to Little Bengal, 14, 177.
10 Clark, The Communitarian Moment, especially 26-9 (quote on 27). For Adam's life see also Hill, "William Adam, Unitarian Missionary"; Sanial, "The Rev. William Adam"; Major, Slavery, Abolitionism and Empire, 321-37.

11 Collet, The Life and Letters, 138; Lavan, Unitarians and India, 57-63; Zastoupil, "Defining Christians, Making Britons," 234-5.

12 Kopf, The Brahmo Samaj, xiii, 7, 12.

13 Robertson, Raja Rammohan Ray, 43. Dermot Killingly also focusses on the breakdown of cooperation; see Killingly, Rammohun Roy, 146.

14 Zastoupil, Rammohun Roy and the Making of Victorian Britain.

15 See Sen, Rammohun Roy, appendix 1, for a list of these publications and Ray, The Religious Ideas for a survey of his writings on religion in Persian, Sanskrit, and Bengali.

16 For Roy's early life see Sen, Rammohun Roy, chapter 2.

17 For the parts played by both Britons and Bengalis in shaping the early colonial city see Chattopadhyay, Representing Calcutta. For trading links with the United States see Bean, Yankee India.

18 Murshid, Bengali Culture, 96-178; Zastoupil and Moir, The Great Indian Education Debate; Mukherjee, "Class, Caste and Politics in Calcutta."

19 For reproductions of the petitions Roy organised against press regulation in India in 1823 see Collet, The Life and Letters, appendix 1, 387-420. For Roy's role as the founder of a tradition of Indian liberal political thought see Bayly, Recovering Liberties.

20 Pennington, Was Hinduism Invented?, 4.

21 For a detailed history of these Baptist missionaries, who were based at the Danish enclave of Serampore, see Potts, British Baptist Missionaries.

22 For discussion of the development of Roy's religious beliefs see Hatcher, Bourgeois Hinduism, 19-32; Killingley, Rammohun Roy in Hindu and Christian Tradition. 
23 Le Bas, The Life of the Right Reverend Thomas Fanshaw Middleton, 1: 178-9, 420-1.

24 Biswas, The Correspondence of Raja Rammohun Roy, letter 4, 1: 38-44.

25 Sastri, History of the Brahmo Samaj, 15-20. For the text of these tracts see Nag and Burman, The English Works, 1: 81-120.

26 Extract from Rammohun Roy's letter to John Digby, 1816/17; reproduced in Biswas, The Correspondence, 1: 19.

27 Potts, British Baptist Missionaries, 148 51; Roy, A Second Conference. For the controversy over suttee see Mani, Contentious Traditions.

28 Roy, The Precepts of Jesus.

29 Marshman, A Defence of the Deity. For further information on the controversy see Collet, The Life and Letters, 11871; Potts, British Baptist Missionaries, 232-43; Thomas, The Acknowledged Christ, 1-37.

30 Roy, An Appeal to the Christian Public.

31 For further information on William Adam's time in India see Sanial, "The Rev. William Adam"; for an outline of his whole life see Hill, "William Adam, Unitarian Missionary."

32 Letter from William Ward to Samuel Hope, Serampore, 7 Nov. 1821, as quoted in Potts, British Baptist Missionaries, 234.

33 Sastri, History of the Brahmo Samaj, 17.

34 This picture of the shifting membership of the Committee has been pieced together from Calcutta Unitarian Committee, Brief Memoir, 29; entries in the Calcutta Unitarian Committee memoranda book [hereafter CUC MB], 1-2, 22-3, 64; a letter from William Adam to R. Dutton, 26 June 1827, as quoted in Collet, The Life and Letters, 137 (footnote); Calcutta Unitarian Committee, Second Memoir, appendix, 42; and Adam, The Principles and Objects, 32. Arnot was assistant editor of the Calcutta Journal, whose editor, Roy's friend James Silk Buckingham, was highly critical of the colonial government and was also expelled from India (see Collet, The Life and Letters, 179).
35 For Bengali women's emergence into the public sphere see Borthwick, The Changing Role, and Murshid, Reluctant Debutante; for women's changing position within British Unitarianism see Watts, Gender, Power and the Unitarians, and Gleadle, The Early Feminists; for American Unitarian women see Emerson, Standing Before Us, and Wayne, Women Thinking.

36 Its social composition contrasted with that of the Indian Unitarian Christian congregation set up in Madras seven years earlier by William Roberts (née Moodelliar Vellazha), a low-caste and impoverished Tamil Hindu convert to Christianity. Roberts corresponded with the Unitarian Society of London from 1816 onwards and it later put Adams in contact with Roberts: see Lavan, Unitarians and India, 24-31; Collet, The Life and Letters, 166-8, note 3.

37 Calcutta Unitarian Committee, Second Memoir, appendix, 41-2.

38 For an overview of Unitarian beliefs see Chryssides, The Elements of Unitarianism.

39 Adam, The Principles and Objects, 9.

40 Killingley, Rammohun Roy in Hindu and Christian Tradition. Following Brian Hatcher, I use the term "eclectic," in implying selective appropriation, in preference to the term "syncretic," implying the fusion of different traditions, to describe Roy's religious approach. See Hatcher, Eclecticism and Modern Hindu Discourse, especially 3-21.

41 Adam, The Principles and Objects, 8, 26.

42 Ibid.,7.

43 Calcutta Unitarian Committee, Second Memoir, 12-13.

44 Ibid.16; Rammohun Roy, letter to Rev. William Adam, 4 Dec. 1824, reproduced in Biswas, The Correspondence, 1: 347.

45 Calcutta Unitarian Committee, Brief Memoir, 31. The list of subscriptions to the chapel fund from Calcutta residents which was published in 1825 shows nine Bengalis among the twenty-seven subscribers, with Roy pledging the largest amount. 
46 Prospectus of the Unitarian Repository, and Christian Miscellany; The Unitarian Repository and Christian Miscellany.

47 Calcutta Unitarian Committee, Second Memoir, 23.

48 This publication (which I have been unable to trace) is mentioned in the letter from Rev. W. Adam, Calcutta, 28 January1822, to the Secretary of the Unitarian Fund, which was published in the Unitarian Fund Register 1 (1822), 6. Adam states the sermon was delivered in Boston, but he may well be referring to the landmark sermon "Unitarian Christianity" which Channing delivered in Baltimore in May 1819; this marked the emergence of Unitarianism in the United States as a distinctive movement characterised by rejection of the Trinity, belief in human goodness, and the subjection of religious belief to the light of reason.

49 Roy, Final Appeal to the Christian Public.

50 Roy, Translation of the Cena Upanishad; Roy, Brief Remarks Regarding Modern Encroachments on the Ancient Rights of Females; Roy, Bengalee Grammar in the English Language.

51 Calcutta Unitarian Committee, Brief Memoir, 6.

52 Letter from Rev. W. Adam, Calcutta, 28 January 1822 , to the Secretary of the Unitarian Fund, Unitarian Fund Register 1 (1822), 1-6.

53 The Unitarian Repository, and Christian Miscellany 1:1 (October 1823), 6.

54 This correspondence was later published as Ware, Correspondence.

55 Ware, Correspondence, 90, 91, 96-7, $100-1,106$.

56 Ibid., 123-4.

57 Ibid., 125-6.

58 Ibid., 136.

59 For a full list of subscriptions from overseas see Calcutta Unitarian Committee, Brief Memoir, 32-44.

60 Brief Memoir, 3-4, 4-5.

61 CUC MB, 1-28.

62 These letters were published as Adam, The Principles and Objects. The
Society for the Promotion of Christianity in India was also known as the Boston India Association; for its founding committee members see Calcutta Unitarian Committee, Brief Memoir, 30.

63 Tuckerman, A Letter on the Principles of Missionary Enterprise, 37.

64 Calcutta Unitarian Committee, Second Memoir, 11-12.

65 Ibid., 12-18.

66 Ibid., 17.

67 Ibid.,18-19.

68 Adam, The Principles and Objects; CUC MB, 43-6.

69 CUC MB, 32, 33, 59-61.

70 Adam, The Principles and Objects; CUC MB, 43-6.

71 CUC MB, 45-6, 59-64.

72 Calcutta Unitarian Committee, Second Memoir, preface.

73 CUC MB, 67-85.

74 Ibid., 86ff. (the following pages are unnumbered. See entries for 11 June, 30 June, 18 July 1828).

75 Ibid., entry for 26 July 1828.

76 As evidenced by their signatures appended to Adam's circulars to Committee members between 24 November 1828 and 9 November 1829 , which marked the final winding down of the group. See CUC MB, n.p.

77 Collet, The Life and Letters, 220, quoting letters from William Adam to John Bowring, 5 February 1828, and to Joseph Tuckerman, 2 April 1828.

78 Collet, The Life and Letters, 219; Sastri, History of the Brahmo Samaj, 25.

79 Letter from William Adam to Joseph Tuckerman, Calcutta, 22 January 1829, as quoted in Collet, The Life and Letters, 221.

80 CUC MB, entry for 9 November 1829.

81 Trust Deed of the Brahmo Samaj, reproduced in Collet, The Life and Letters, appendix 4.

82 Kopf, The Brahmo Samaj; Sastri, History of the Brahmo Samaj.

83 "Rules of the Calcutta Unitarian Committee" in Adam, The Principles and Objects,31-32, 
84 A list of publications in England is included in Sen, Rammohun Roy, appendix 1, 192 4; an early publication, facilitated by his friend John Digby, was Rammohun Roy, Translation of an Abridgment; see also extract from Rammohun Roy's letter to John Digby,1816/17, as printed in Biswas, The Correspondence, 1: 20.

85 See Biswas, The Correspondence, 1: 87162.

86 A new edition of this was published in 1824 with a portrait of Roy and the addition of his Final Appeal.

87 Rammohun Roy letter to Rev. Jared Sparks, 17 October 1822, as reproduced in Biswas, The Correspondence, 1: 6671; Rammohun Roy letter to Rev. Jared Sparks, 9 December 1822, Biswas, The Correspondence, 1: 71-5.

88 Roy letter to Sparks, 9 December 1822. For more information on Roy and American Unitarians see Moore, Rammohun Roy and America; Lavan, Unitarians and India, 32-40.

89 Rammohun Roy's letter to David Reed, 13 January 1824 (published in the Christian Register, 7 May 1824, 154) is reproduced in Biswas, The Correspondence, 1: 266.

90 Ware, Correspondence, 124.

91 See Sen, Rammohun Roy, appendix 1, 194-5, for a list of American publications of his work.

92 For a full discussion of Roy's stay in England and analysis of his impact on Unitarians there see Zastoupil, Rammohun Roy and the Making of Victorian Britain.

93 Hatcher, Bourgeois Hinduism, provides a detailed discussion of the religious orientation of the organisation under Debendranath Tagore.

94 For the significance of the sustained collective commemoration of Roy by both
Brahmos and Unitarians to the maintenance of their sense of connection see Midgley, "Transoceanic Commemoration."

95 Stevens, Keshab; Kopf, The Brahmo Samaj, 249-86; Midgley, "Mary Carpenter"; Lavan, Unitarians and India, 81-103.

96 Adam, Reports on the State of Education in Bengal.

97 For a new study of the American radical abolitionist followers of William Lloyd Garrison, which stresses their close ties with activists and liberal thinkers in both Britain and Europe, see McDaniel, The Problem of Democracy in the Age of Slavery. For British Unitarians' involvement in the campaign against American slavery see Stange, British Unitarians against American Slavery. Surprisingly, neither study mentions William Adam.

98 Proceedings of the General Anti-Slavery Convention.

99 Adam, "Slavery in India.". For this phase of Adam's life see Major, Slavery, Abolitionism and Empire, 321-37.

100 Adam, The Law and Custom of Slavery in British India (Cambridge, Mass., 1840), 6, as quoted in Lavan, Unitarians and India, 54.

101 Extract from the Constitution of the Northampton Association, as quoted in Clark, The Communitarian Moment, 60.

102 This was later published in Calcutta in 1879; see Adam, A Lecture on the Life and Labours of Rammohun Roy.

103 See Harrison, Quest for the New Moral World; Guarneri, The Utopian Alternative; Taylor, Eve and the New Jerusalem; Kolmerton, Women in Utopia.

104 For an important new study emphasising the violence on which British rule over India was based see Wilson, India Conquered.

\section{Bibliography}

\section{Unpublished Primary Sources}

Calcutta Unitarian Committee's memoranda book, 1825-1829. Dr. Williams's Library, London.

Temporary ref: B\&FUA/India/ [CUC MB] 


\section{Published Primary Sources}

Adam, William. A Lecture on the Life and Labours of Rammohan Roy. Calcutta, G.P. Roy, 1879. Repr. as A Lecture on the Life and Labours of Rammohun Roy, 2nd ed., eds. Rakhal-Das Haldar, Dilip Kumar Biswas, and Sadharan Brahmo Samaj. Calcutta: D.P. Mitra on behalf of Publication Committee [of] Sadharan Brahmo Samaj, 1977.

- The Principles and Objects of the Calcutta Unitarian Committee Stated in a Letter to Rev. W. J. Fox, Foreign Secretary to the British and Foreign Unitarian Association and to Rev. J. Tuckerman D.D. Secretary to the Boston Indian Association. Calcutta: Printed at the Unitarian Press for the Calcutta Unitarian Committee, 1827.

— Report on the State of Education in Bengal. Calcutta: G.H. Huttmann, Bengal Military Orphan Press, 1835-1838. Repr. As Reports on the State of Education in Bengal, 1835 \& 1838, ed. Anathnath Basu. Calcutta: University of Calcutta, 1941.

—. Slavery in India. Paper Presented to the General Anti-Slavery Convention (London, 1840).

Biswas, Dilip Kumar, ed. The Correspondence of Raja Rammohun Roy. 2 vols. Calcutta: Saraswat Library, 1992.

Brahmunical Magazine, Calcutta, nos 1-3,1821, no 4,1823.

British Indian Advocate (London), 1841-42.

Calcutta Unitarian Committee. Brief Memoir Respecting the Objects and Means of Establishing a Unitarian Mission in Bengal. Calcutta: Unitarian Press, 1825.

Calcutta Unitarian Committee. Second Memoir Respecting the Unitarian Mission in Bengal. Calcutta: V. Holcroft at the Asiatic Press, 1828.

Collet, Sophia Dobson, comp. and ed., The Life and Letters of Raja Rammohun Roy. London: 1900. Repr. As The Life and Letters of Raja Rammohun Roy. 4th ed., ed. D. K. Biswas and P. C. Ganguli. Calcutta: Sadharan Brahmo Samaj, 1988.

Ghose, Jogendra Chunder, The English Works of Raja Rammohun Roy. Calcutta: Bengal Press, 1901. 3 vols. Repr. as Nag, Kalidas, and Debajyoti Burman, eds. The English Works of Raja Rammohun Roy. New edition. Calcutta: Sadharan Brahmo Samaj, 1945.

Marshman, Joshua. A Defence of the Deity and Atonement of Jesus Christ, in Reply to Ram-Mohun Roy of Calcutta. London, 1822.

Proceedings of the General Anti-Slavery Convention, Called by the Committee of the British and Foreign Anti-Slavery Society, and Held in London, from Friday, June 12th, to Tuesday, June 23rd, 1840. London, 1840.

Prospectus of the Unitarian Repository, and Christian Miscellany. Calcutta, 12 September 1823.

Robertson, Bruce Carlisle, ed. The Essential Writings of Raja Rammohan Roy. Delhi: Oxford University Press, 1999.

Roy, Rammohun. An Appeal to the Christian Public in Defence of "The Precepts of Jesus." 1820.

- Bengalee Grammar in the English Language. Calcutta: Unitarian Press, 1826.

- Brief Remarks Regarding Modern Encroachments on the Ancient Rights of Females, According to the Hindoo Law of Inheritance. Calcutta: Unitarian Press, 1822.

- Final Appeal to the Christian Public in Defence of the "Precepts of Jesus. " Dhurrumtollah: Unitarian Press, 1823.

- The Precepts of Jesus: The Guide to Peace and Happiness. Calcutta: 1820.

- The Precepts of Jesus, the Guide to Peace and Happiness [. . .] To Which Are Added, the

First, Second, and Final Appeal to the Christian Public [. . .]. London: Unitarian Society, 1824.

- A Second Conference between an Advocate and an Opponent of the Practice of Burning Widows Alive. Calcutta: Baptist Mission Press, 1820.

- Translation of an Abridgment of the Vedant [. . .] Likewise a Translation of the Cena Upanishad [. . . ]. London: Printed for T. and J. Holitt, 1817.

- Translation of the Cena Upanishad. Calcutta: Unitarian Press, 1823.

Tuckerman, Joseph. A Letter on the Principles of Missionary Enterprise. Boston: I. R. Bitts, 1826. 
Unitarian Fund Register 1. 1822.

The Unitarian Repository and Christian Miscellany, vol. 1, nos. 1-12 (Oct. 1823-Dec. 1824).

Ware, Henry Sr. Correspondence Relative to the Prospects of Christianity and Promoting Them in India. Cambridge, Mass: University Press, 1824; reprinted London: C. Fox \& Co, 1825.

\section{Secondary Sources}

Alavi, Seema. Muslim Cosmopolitanism in the Age of Empire. Cambridge, Mass: Harvard University Press, 2015.

Bagchi, Barnita. "Many Modernities and Utopia: From Thomas More to South Asian Utopian Writings." In Pablo Guerra, ed., Utopia: 500 Años, 195-220. Bogota: Universidad Cooperativa de Colombia, 2016. http://dx.doi.org/10.16925/9789587600544.

_ - ed. Sultana's Dream and Padmarag : Two Feminist Utopias by Rokeya Sakhawat Hossain. New Delhi: Penguin Books India, 2005.

_ . "Towards Ladyland: Rokeya Sakhawat Hossain and the Movement for Women's Education in Bengal, c. 1900-c. 1932. Paedagogica Historica 45:6 (December 2009), 743-55.

Bayly, C. A. Recovering Liberties: Indian Thought in the Age of Liberalism and Empire. Cambridge: Cambridge University Press, 2012.

Bean, Susan S. Yankee India: American Commercial and Cultural Encounters with India in the Age of Sail, 1784-1860. Salem, Mass: Peabody Essex Museum, 2001.

Borthwick, Meredith. The Changing Role of Women in Bengal, 1849-1905. Princeton, N.J.: Princeton University Press, 1984.

Bose, Sugata, and Kris Manjapra, eds. Cosmopolitan Thought Zones: South Asia and the Global Circulation of Ideas. Basingstoke: Palgrave Macmillan, 2010.

Chattopadhyay, Swati. Representing Calcutta: Modernity, Nationalism and the Colonial Uncanny. London: Routledge, 2006.

Chryssides, George. The Elements of Unitarianism. Shaftesbury: Element Books, 1998.

Clark, Christopher. The Communitarian Moment: The Radical Challenge of the Northampton Association. Amherst, Mass: University of Massachusetts Press, 1995.

Dutton, Jacqueline. "Non-Western Utopian Traditions." In The Cambridge Companion to Utopian Literature, ed. Gregory Claeys, 223-58. Cambridge: Cambridge University Press, 2010.

Emerson, Dorothy May. Standing Before Us: Unitarian Universalist Women and Social Reform, 1776-1936. Boston: Skinner House Books, 2000.

Gleadle, Kathryn. The Early Feminists: Radical Unitarians and the Emergence of the Women's Rights Movement, 1831-51. Basingstoke: Macmillan, 1995.

Guarneri, Carl J. The Utopian Alternative: Fourierism in Nineteenth-Century America. Ithaca, N.Y.: Cornell University Press, 1991.

Harrison, J. F. C. Quest for the New Moral World: Robert Owen and the Owenites in Britain and America. New York, 1969.

Hatcher, Brian A. Bourgeois Hinduism, or the Faith of the Modern Vedantists. Oxford: Oxford University Press, 2008.

—. Eclecticism and Modern Hindu Discourse. Oxford: Oxford University Press, 1999.

Hill, Andrew. "William Adam, Unitarian Missionary." Transactions of the Unitarian Historical Society 21:1 (April 1995), 30-41.

Joshi, V. C., ed. Rammohun Roy and the Process of Modernization in India. Delhi: Vikas Publishing House, 1975.

Killingley, Dermot. Rammohun Roy in Hindu and Christian Tradition: The Teape Lectures. Newcastle upon Tyne: Grevatt \& Grevatt, 1993.

Kleingeld, Pauline. Kant and Cosmopolitanism: The Philosophical Ideal of World Citizenship. Cambridge: Cambridge University Press, 2012. 
Kolmerton, Carol F. Women in Utopia: The Ideology of Gender in the American Owenite Communities. Bloomington: Indiana University Press, 1990.

Kopf, David. The Brahmo Samaj and the Shaping of the Modern Indian Mind. New Delhi: Atlantic, 1996.

Lavan, Spencer. Unitarians and India: A Study in Encounter and Response. 2nd ed. Boston: Skinner House, 1984.

Le Bas, Charles Webb. The Life of the Right Reverend Thomas Fanshaw Middleton, D. D., Late Lord Bishop of Calcutta. 2 vols. London: C. J. G. \& F. Rivington, 1831.

Major, Andrea. Slavery, Abolitionism and Empire in India, 1772-1843. Liverpool: Liverpool University Press, 2012.

Mani, Lata. Contentious Traditions: The Debate on Sati in Colonial India. Berkeley: University of California Press, 1998.

Manuel, Frank E., and Fritzie P. Manuel. Utopian Thought in the Western World. Oxford: Basil Blackwell, 1979.

McDaniel, W. Caleb. The Problem of Democracy in the Age of Slavery: Garrisonian Abolitionists and Transatlantic Reform. Baton Rouge: Louisiana State University Press, 2013.

Midgley, Clare. "Mary Carpenter and the Brahmo Samaj of India: A Transnational Perspective on Social Reform in the Age of Empire." Women's History Review 22:2 (2013), 363-86.

—. "Transoceanic Commemoration and Connections between Bengali Brahmos and British and American Unitarians.” Historical Journal 54:3 (Sept. 2011), 773-96.

Mohan, Anupama. Utopia and the Village in South Asian Literatures. Basingstoke: Palgrave Macmillan, 2012.

Moore, Adrienne. Rammohun Roy and America. Calcutta: Sadharan Brahmo Samaj, 1942.

Mukherjee, S. N. "Class, Caste and Politics in Calcutta, 1815-38." In Elites in South Asia, ed. E. Leach and S. N. Mukherjee. Cambridge: Cambridge University Press, 1970.

Müller, Anja, and Clare Wallace, eds. Cosmotopia: Identities in David Greig's Theater. Prague: Litteraria Pragensia Books, 2011.

Murshid, Ghulam. Bengali Culture over a Thousand Years. New Delhi: Niyogi Books, 2018.

- Reluctant Debutante: Response of Bengali Women to Modernization, 1849-1905. Rajshahi: Sahitya Samsad, 1983.

Pennington, Brian K. Was Hinduism Invented? Britons, Indians, and the Colonial Construction of Religion. Oxford: Oxford University Press, 2005.

Pohl, Nicole. "Utopianism after More: The Renaissance and Enlightenment." In The Cambridge Companion to Utopian Literature, ed. Gregory Claeys, 51-78. Cambridge: Cambridge University Press, 2010.

Potts, E. Daniel. British Baptist Missionaries in India 1793-1837: The History of Serampore and Its Missions. Cambridge: Cambridge University Press, 1967.

Ray, Ajit Kumar, The Religious Ideas of Rammohun Roy. A Survey of his Writings on Religion Particularly in Persian, Sanskrit and Bengali. New Delhi: Kanak Publications, 1976.

Robbins, Bruce, and Paulo Lemos Horta, eds. Cosmopolitanisms. New York: New York University Press, 2017.

Robertson, Bruce Carlisle. Raja Rammohan Ray: The Father of Modern India. New Delhi: Oxford University Press, 1999.

Sanial, S. C. "The Rev. William Adam." Bengal Past and Present 8 (1914): 251-72.

Sastri, Sivanath. History of the Brahmo Samaj. 2nd ed. Calcutta: Sadharan Brahmo Samaj, 1974.

Sen, Amiya P. Rammohun Roy: A Critical Biography. Delhi: Penguin Viking, 2012.

Slate, Nico. Colored Cosmopolitanism: The Shared Struggle for Freedom in the United States and India. Cambridge, Mass.: Harvard University Press, 2012.

Stange, Douglas Charles. British Unitarians against American Slavery, 1833-6. Cranbury, N.J.: Associated University Press, 1984. 
Stevens, John A. Keshab: Bengal's Forgotten Prophet. London: C. Hurst, 2018.

Taylor, Barbara. Eve and the New Jerusalem: Socialism and Feminism in the Nineteenth Century. London: Virago, 1983.

Thomas, M. M. The Acknowledged Christ of the Indian Renaissance. London: SCM Press, 1969. Van der Veer, Peter. "Colonial Cosmopolitanism." In Conceiving Cosmopolitanism: Theory, Context, and Practice, ed. Steven Vertovec and Robin Cohen, 165-79. Oxford: Oxford University Press, 2002.

Watts, Ruth. Gender, Power and the Unitarians in England, 1760-1860. Harlow, Essex: Addison Wesley Longman, 1998.

Wayne, Tiffany K. Women Thinking: Feminism and Transcendentalism in Nineteenth-Century America. Lanham, Md.: Lexington Books, 2005.

White, Daniel E. From Little London to Little Bengal: Religion, Print and Modernity in Early British India, 1793-1835. Baltimore: Johns Hopkins University Press, 2013.

Wilson, Jon. India Conquered: Britain's Raj and the Chaos of Empire. London: Simon and Schuster, 2016.

Zastoupil, Lynn. "Defining Christians, Making Britons: Rammohun Roy and the Unitarians." Victorian Studies 44:2 (Winter 2002), 215-43.

- Rammohun Roy and the Making of Victorian Britain. New York: Palgrave Macmillan, 2010.

— and M. Moir, eds. The Great Indian Education Debate: Documents Relating to the Orientalist-Anglicist Controversy of 1780-1840. London: Curzon, 1999. 